\section{Mechanized Harvest of Southern Highbush Blueberries for the Fresh Market: An Introduction and Overview of the Workshop Proceedings}

\author{
Jeffrey G. Williamson ${ }^{1,3}$ and William O. Cline ${ }^{2}$
}

AdDITIONAL INDEX wORDs. Vaccinium, rabbiteye, mechanical harvesting, fruit quality, postharvest storage, fruit firmness

$\mathrm{T}$ he development of mechanical devices to assist in harvesting cultivated blueberries (Vaccinium species and hybrids) began in the late 1950s. In 1958, U.S. Department of Agriculture engineers located at Michigan State University developed handheld shakers that were used with fabric-lined catch frames as aids for harvesting processed blueberries (Hedden et al., 1959; Monroe and Levin, 1966). These devices substantially increased worker productivity and reduced harvest costs by $\approx 55 \%$ (Monroe and Levin, 1966). By 1963, $35 \%$ of the Michigan crop and $20 \%$ of the New Jersey crop were harvested in this fashion. Later Monroe and Levin (1966) described their early attempts to develop a continuous over-the-row blueberry harvester, which required a driver and two additional workers. Testing of over-the-row harvesters began in the late 1950s and by 1966 over-the-row harvesters were available commercially in the United States. Eck (1988) reported that over 100 such machines were in use in the United States by 1971. One of the earliest commercial models, the Harvey Harvester, was featured in an article entitled "Fantastic New Farm Machines" in Popular Mechanics in 1970 (Lamm, 1970). Over time, various harvesters were developed that used different methods to remove ripe berries from canes and they were

This paper was part of the workshop " Mechanized Harvest of Blueberries for the Fresh Market" held 2 Aug. 2012 at the ASHS Conference, Miami, FL, and sponsored by the Viticulture and Small Fruits (VSF) Working Group.

${ }^{1}$ Horticultural Sciences Department, University of Florida, 2113 Fifield Hall, Gainesville, FL 32611

${ }^{2}$ Horticultural Crops Research Station, North Carolina State University, 3800 Castle Hayne Road, Castle Hayne, NC 28429

${ }^{3}$ Corresponding author. E-mail: jgrw@ufl.edu. generally classified as slappers, sway shakers, and rotary shakers (Brown et al., 1996; Mainland, 1993). In their review, Dale et al. (1994) provide a detailed account of blueberry harvester designs up through the early 1990s.

Over-the-row harvesters were reported to increase worker productivity by almost 60 times and reduce the cost of harvesting by up to $85 \%$ (Brown et al., 1996). However, numerous problems were soon identified with harvesting blueberries mechanically. The primary ones were 1 ) ground loss of otherwise marketable fruit, 2) detachment of immature berries, 3 ) reduced berry firmness and quality, and 4) increased postharvest decay and reduced storage life. Machine harvest necessitates increased handling of fruit during grading and sorting, and on blueberries most postharvest decay occurs at the detachment point - the newly exposed stem scar (Ballinger et al., 1978). When both fungal spores and moisture are present on packing lines, this extra handling can greatly increase postharvest decay caused by fungi (Alternaria, Colletotrichum) due to the exposure (rolling) of berries over contaminated surfaces (Cline, 1996).

In the first comprehensive report directly comparing the effects of machine and hand harvesting on highbush blueberry ( $V$. corymbosum), Mainland et al. (1975) found that losses of marketable fruit of 'Wolcott', 'Jersey', 'Morrow', and 'Murphy' were from $19 \%$ to $44 \%$ greater for machine harvesting than for hand harvesting.
Machine-harvested fruit were $10 \%$ to $38 \%$ softer than hand-harvested fruit, and soft berries were difficult to identify and remove during grading. Moreover, after $7 \mathrm{~d}$ of storage at $21^{\circ} \mathrm{C}$, there was $11 \%$ to $41 \%$ more postharvest decay for the machine-harvested fruit. They concluded that the inability to remove bruised fruit during grading and sorting presented serious problems for maintaining quality during storage. Similar reductions in marketable yield from mechanical harvesting were reported in Michigan by Howell et al. (1976). In general, increased berry softening and decay during storage have been widely reported in association with mechanical blueberry harvesting (Ceponis and Cappellini, 1979; Dale et al., 1994; Howell et al., 1976; Mainland et al., 1971, 1975; Milholland and Jones, 1972). Ballinger et al. (1973) studied factors affecting blueberry firmness and emphasized the importance of careful harvesting and handling procedures, noting that blueberries are easily bruised, leading to softening and subsequent decay during storage. In a review of the literature, Morris (1983) stated that "decay of machineharvested blueberries during postharvest holding is perhaps the biggest problem of the industry."

Reductions in berry firmness and marketable yield were also found for machine-harvested rabbiteye blueberry ( $V$. virgatum). Using the rabbiteye blueberry cultivar Tifblue, Austin and Williamson (1977) reported increased ground loss of marketable fruit, reduced fruit firmness, and more than twice the amount of unmarketable fruit from machine harvesting vs. hand harvesting. Increased berry softening following machine harvesting was also noted for 'Climax' and 'Woodard' (Miller and Smittle, 1987) and 'Brightwell' (NeSmith et al., 2002), although depending on cultivar, the softer machine-harvested fruit may still be considered marketable as fresh fruit. NeSmith et al. (2002) proportionally attributed the causes of 'Brightwell' rabbiteye berry softening to the following harvest activities: $20 \%$ to $30 \%$ loss of firmness due to

\begin{tabular}{llll}
\hline $\begin{array}{l}\text { Units } \\
\text { To convert U.S. to SI, } \\
\text { multiply by }\end{array}$ & U.S. unit & SI unit & $\begin{array}{l}\text { To convert SI to U.S., } \\
\text { multiply by }\end{array}$ \\
\hline$\left({ }^{\circ} \mathrm{F}-32\right) \div 1.8$ & ${ }^{\circ} \mathrm{F}$ & ${ }^{\circ} \mathrm{C}$ & $\left({ }^{\circ} \mathrm{C} \times 1.8\right)+32$
\end{tabular}


mechanical harvesting; $10 \%$ to $15 \%$ loss of firmness due to grading and sorting; and $4 \%$ to $8 \%$ loss of firmness due to storing fruit at ambient temperature for $24 \mathrm{~h}$ after harvest compared with cooling fruit immediately.

Three postharvest innovations have greatly increased the feasibility of machine-for-fresh blueberry harvesting: the development of color sorters to remove underripe fruit, the development of soft berry sorters to remove damaged and overripe fruit, and the use of postharvest forced-air cooling to rapidly stabilize and dry fruit immediately after harvest. Early work on sorting by ripeness included both light transmittance and optical sorting, and these methods form the basis of current color sorting technology (Ballinger and Kushman, 1971; McClure and Rohrbach, 1971). Soon afterward, advances in mechanized soft berry sorting were reported by Hamann et al. (1973) and Bower and Rohrbach (1976). Color and soft berry sorters are now commonly used in blueberry packing lines. Forced-air cooling procedures developed for fresh blueberries are also standard throughout the blueberry industry (Boyette et al., 1993).

Mechanical harvesters have been reported to cause damage to blueberry plants (Mainland et al., 1975; Howell et al., 1975). Skinned areas and broken canes caused by harvesters may serve as entry points for disease organisms such as Botryosphaeria sp. (Mainland et al., 1975). Howell et al. (1975), working with 'Jersey' highbush blueberry, attributed cane loss from winter injury to wounds from mechanical harvesters. They found that the amount of wood lost was proportional to the vibration rates of the harvester. At high rates, loss of fruiting wood was sufficient to reduce production the following year. Mainland (1993) emphasized the importance of hand pruning to narrow the plant base and remove old canes with many branch shoots if plants are to be harvested mechanically. Strik and Buller (2002) reported a reduction for ground loss during mechanical harvesting by using a two-wire trellis system on 'Bluecrop' highbush blueberry in Oregon.

Experimental harvesters have been developed to address the problems associated with mechanical harvesting of blueberries for fresh consumption.
Peterson and Brown (1996) reported results from an experimental mechanical harvester that used an angled shaker, a cane spreading and repositioning system to spread canes away from the plant crown and reduce the fruit drop distance, and padded surfaces designed to reduce drop impacts. They concluded that the experimental harvester resulted in better fruit quality than a conventional harvester but there was need for further improvement. One year later, Peterson et al. (1997) reported results from another experimental harvester designed for fresh fruit harvest known as the V45 harvester. It also used a cane dividing system, an angled shaker, and padded catching surfaces but was narrow enough to maneuver effectively in cultivated blueberry plantings. Ground losses were reduced by $44 \%$ compared with a conventional harvester. The pack outs for the V45 were as good as or better than those obtained from a rotary harvester and internal berry quality was superior to the rotary harvester. In 2005 , Takeda et al. (2008) evaluated the V45 harvester using specially pruned rabbiteye blueberry and southern highbush blueberry ( $V$. corymbosum hybrids) plants with v-shaped canopies. For rabbiteye, internal bruising and skin splitting were less for the V45 harvester than for a sway harvester and nearly equal to hand-harvested fruit. They concluded that the V45 harvester had potential for harvesting some rabbiteye blueberry cultivars for fresh fruit consumption. However, cane pruning and training requirements and limited ground speed has prevented widespread commercialization of the $\mathrm{v}-45$ harvester (Takeda et al., 2008).

Despite the many challenges, a trend toward increased machine harvesting of blueberries for fresh markets has been noted during the past two decades. A 1992 survey of the North American blueberry industry revealed that $40 \%$ of the North American blueberry crop was machine harvested, of which $77 \%$ was used for processing, and 23\% was sold for fresh consumption (Moore, 1994). Almost all respondents in the largerproducing states expected machine harvesting to increase in the future. From a similar survey conducted about a decade later, Strik and Yarborough (2005) concluded that a major change in the last 10 years was the use of machine harvesting for fresh blueberries. For most states with significant blueberry production, a substantial percentage of berries grown for fresh consumption were machine harvested and this trend was expected to continue. Examples of companies currently producing self-propelled, over-the-row commercial blueberry harvesters include BEI International (South Haven, MI), Oxbo International (Lynden, WA), and Littau Harvester (Stayton, OR).

Further transition from handharvesting to machine-harvesting blueberries for fresh consumption appears inevitable. The problems associated with mechanical harvesting of blueberries were identified decades ago for processed fruit but are now intensified because of the higher quality requirements for fresh fruit. The challenges moving forward include but are not limited to l) improved cultivars with characteristics that lend themselves to machine harvesting; 2) modifications of cultural and postharvest practices needed to reduce losses of marketable yield that occur during and after machine harvest; and 3 ) improvements in harvester design needed to increase harvest efficiency, improve berry quality, and minimize plant injury. The scope and nature of these problems require a multidisciplinary approach. The following proceedings represent findings and opinions of leading researchers from a variety of disciplines, all with the common goal of developing an integrated system for mechanically harvesting southern highbush blueberries for fresh markets. Specifically, the following topics are discussed: 1) use of sparkleberry ( $V$. arboreum) in breeding to improve traits of southern highbush blueberry for mechanical harvesting; 2) effects of mechanical harvesting on postharvest quality of southern highbush blueberry; 3 ) cultural practices and other preharvest considerations to improve mechanical harvesting efficiency; and 4) analyses of points of impact to berries during harvesting with a rotary mechanical harvester.

\section{Literature cited}

Austin, M.E. and R.E. Williamson. 1977. Comparison of harvest methods of rabbiteye blueberries. J. Amer. Soc. Hort. Sci. 102:454-456. 
Ballinger, W.E. and L.J. Kushman. 1971. Light transmittancy versus sizing as a means of sorting blueberries for quality. Highbush Blueberry Mechanization Symp., 1-2 Nov. 1971, North Carolina State University, Raleigh. p. 127-134.

Ballinger, W.E., L.J. Kushman, and D.D. Hamann. 1973. Factors affecting the firmness of highbush blueberries. J. Amer. Soc. Hort. Sci. 98:583-587.

Ballinger, W.E., E.P. Maness, and W.F. McClure. 1978. Postharvest decay of blueberries as influenced by stem attachment and ripeness. Plant Dis. Rptr. 62: 316-319.

Bower, D.R. and R.P. Rohrbach. 1976. Application of vibrational sorting to blueberry firmness separation. Trans. Amer. Soc. Agr. Eng. 19:185-191.

Boyette, M.D., E.A. Estes, C.M. Mainland, and W.O. Cline. 1993. Postharvest cooling and handling of blueberries. North Carolina Coop. Ext. Serv. Publ. AG-413-7.

Brown, G.K., N.L. Schulte, E.J. Timm, R.M. Beaudry, D.L. Peterson, J.F. Hancock, and F. Takeda. 1996. Estimates of mechanization effects on fresh blueberry quality. Appl. Eng. Agr. 12:21-26.

Ceponis, M.J. and R.A. Cappellini. 1979. Control of postharvest decays of blueberry fruits by precooling, fungicide, and modified atmospheres. Plant Dis. Rptr. 63:1049-1053.

Cline, W.O. 1996. Postharvest infection of highbush blueberries following contact with infested surfaces. HortScience 31:981-983.

Dale, A., E.J. Hanson, D.E. Yarborough, R.J. McNicol, E.J. Stang, R. Brennan, J.R. Morris, and G.B. Hergert. 1994. Mechanical harvesting of berry crops. Hort. Rev. 16:255-382.

Eck, P. 1988. Blueberry science. Rutgers University Press, New Brunswick, NJ.
Hamann, D.D., L.J. Kushman, and W.E. Ballinger. 1973. Sorting blueberries for quality by vibration. 1973. J. Amer. Soc. Hort. Sci. 98:572-576.

Hedden, S., H.P. Gaston, and J.H. Levin. 1959. Harvesting blueberries mechanically. Michigan Agr. Expt. Sta. Qrtly. Bul 42:24-34.

Howell, G.S., B.G. Stergios, S.S. Stackhouse, and H.C. Bittenbender. 1975. Mechanical harvester vibration rates related to winterkill of highbush blueberry branches. HortScience 10:85.

Howell, Jr., G.S., B.G. Stergios, S.S. Stackhouse, and H.C. Bittenbender. 1976. Ethephon as a mechanical harvesting aid for highbush blueberries (Vaccinium australe Small). J. Amer. Soc. Hort. Sci. 101:111-115.

Lamm, M. 1970. Fantastic new farm machines. Popular Mechanics 133(1):118123 .

Mainland, C.M. 1993. Blueberry production strategies. Acta Hort. 346:111-116.

Mainland, C.M., W.E. Ballinger, and L.J. Kushman. 1971. Recovery firmness and shelf life of hand and machine harvested highbush blueberries. HortScience 6: 309 (abstr.).

Mainland, C.M., L.J. Kushman, and W.E. Ballinger. 1975. The effect of mechanical harvesting on yield, quality of fruit and bush damage of highbush blueberry. J. Amer. Soc. Hort. Sci. 100:129-134.

McClure, W.F. and R.P. Rohrbach. 1971. An automatic optical blueberry sorting machine. Highbush Blueberry Mechanization Symp., 1-2 Nov. 1971, North Carolina State University, Raleigh. p. 135.

Milholland, R.D. and R.K. Jones. 1972. Postharvest decay of highbush blueberry fruit in North Carolina. Plant Dis. Rptr. 56:118-122.
Miller, W.R. and D.A. Smittle. 1987. Storage quality of hand- and machineharvested rabbiteye blueberries. J. Amer. Soc. Hort. Sci. 112:487-490.

Monroe, G.E. and J.H. Levin. 1966. Mechanical harvesting of cultivated blueberries. Trans. Amer. Soc. Agr. Eng. 9:4-5.

Moore, J.N. 1994. The blueberry industry of North America. HortTechnology 4:96-102.

Morris, J.R. 1983. Influence of mechanical harvesting on quality of small fruits and grapes. HortScience 18:412-417.

NeSmith, S.D., S. Prussia, M. Tetteh, and G. Krewer. 2002. Firmness losses of rabbiteye blueberries (Vaccinium ashei Reade) during harvesting and handling. Acta Hort. 574:287-293.

Peterson, D.L. and G.K. Brown. 1996. Mechanical harvester for fresh market quality blueberries. Trans. Amer. Soc. Agr. Eng. 39:823-827.

Peterson, D.L., S.D. Wolford, E.J. Timm, and F. Takeda. 1997. Fresh market quality blueberry harvester. Trans. Amer. Soc. Agr. Eng. 40:535-540.

Strik, B. and G. Buller. 2002. Improving yield and machine harvest efficiency of 'Bluecrop' through high density planting and trellising. Acta Hort. 574:227-231.

Strik, B.C. and D. Yarborough. 2005. Blueberry production trends in North America, 1992 to 2003, and predictions for growth. HortTechnology 15:391-398.

Takeda, F., G. Krewer, E.L. Andrews, B. Mullinix, Jr., and D.L. Peterson. 2008. Assessment of the V45 blueberry harvester on rabbiteye blueberry and southern highbush blueberry pruned to $\mathrm{v}$-shaped canopy. HortTechnology 18: 130-138. 